\title{
RNA Interference and its Application in Crop Protection
}

\author{
Munmi Borah $^{1 *}$ and Naga Charan Konakalla ${ }^{2}$ \\ ${ }^{1}$ Department of Plant Pathology, Assam Agricultural University, Jorhat-785013, Assam, India \\ ${ }^{2}$ Department of Virology, Sri venkateswara University, Tirupati- 517502, \\ Andhra Pradesh, India \\ *Corresponding author
}

\begin{tabular}{|l|}
\hline Ke y w o r d s \\
RNAi, Plant virus, \\
Bacteria, Fungi, \\
Insects
\end{tabular}

\section{A B S T R A C T}

During the last decade, our familiarity of RNA-mediated functions has been greatly amplified with the invention of tiny non-coding RNAs that play a central role during a method referred to as RNA silencing. RNAi has revolutionized the chances for making custom "knock-downs" of cistron activity. RNAi operates in each plants and animals, and uses double stranded RNA (dsRNA) as a trigger that targets homologous mRNAs for degradation or inhibiting its transcription or translation, where by vulnerable genes are often suppressed. This RNA-mediated cistron management technology has provided new technologies for developing eco-friendly molecular tools for crop enhancement by suppressing the particular genes those are responsible for numerous stresses and as well as disease resistance. This review, updates the current state on the use of RNAi, molecular principles underlying the biology of this phenomenon, development of RNAi technologies in relation to plants and discusses strategies and applications of this technology in plant disease management.

\section{Introduction}

The effective control of plant pathogens on economically important crop species is the major challenges for sustainable agricultural production. Although plant breeding has been the traditional method of manipulating the plant genome to develop resistant cultivar for controlling plants diseases, the introduction of genetic engineering technology provides an entirely new approach. Presently, the cultivated area of genetically modified crops that are resistant to disease is less compared with that of crops for tolerance to herbicide, or resistant to insects. Various strategies have been put forward to render plants resistant to fungi, bacteria, viruses and nematodes. Recently, RNA interference (RNAi) 
technology has appeared to be a promising and efficient technology. The advancement of RNAi as a novel non-transgenic gene therapy against fungal, viral and bacterial infection in plants lies in the fact that it controls the gene expression via mRNA degradation, repression of translation and by chromatin remodeling through small non-coding RNAs. The RNA silencing mechanisms are guided by processing products of the dsRNA degradation by DICER like proteins, which are known as small interfering RNAs (siRNAs) and microRNAs (miRNAs).

The application of inducible gene silencing or tissue-specific gene silencing, with the use of suitable promoters to silence several genes simultaneously should enhance researcher's capacity to protect crops against destructive pathogens.

'RNA interference' refers to diverse RNA based processes that all result in sequencespecific inhibition of gene expression, either at the transcription or translational levels. It has most likely been evolved as a potent mechanism for cells to suppress foreign genes.

The combining features of this phenomena includes the production of small RNAs (21-26 nucleotides (nts) that act as sequence-specific determinants for down-regulating gene expression(Waterhouse et al., 2001; Hannon 2002; Pickford and Cogoni2003) and the requirement of one or additional members of the Argonaute proteins (Hammond et al., 2001). RNAi operates by triggering the action of dsRNA intermediates, which are processed into RNA duplexes of 21-24 nts by a ribonuclease III-like enzyme called Dicer (Fire et al., 1998; Bernstein et al., 2001). After produced, these small RNA molecules or siRNAs are assimilated into a multi-subunit complex called RNA induced silencing complex or RISC (Hammond et al., 2000; Tang et al., 2003). RISC is produced by a
siRNA and an endonuclease among other components. The siRNAs within RISC act as a guide to target the degradation of complementary messenger RNAs (mRNAs) (Hammond et al., 2000; Tang et al., 2003). The host genome encodes for small RNAs called miRNAs that are responsible for endogenous gene silencing. The dsRNAs triggering gene silencing can be initiated from several sources such as expression of endogenous or transgenic antisense sequences, expression of inverted repeated sequences or RNA synthesis during viral replication (Voinnet, 2005).

The remarkable feature of RNA silencing in plants is that once it is triggered in a certain cell, a mobile signal is formed and spread through the whole plant causing the entire plant to be silenced (Dunoyer et al., 2007). After triggering RNA silencing mechanism, the mobile signaling molecules can be relayamplified by production of dsRNAs on the primary cleavage of product templates or by their cleavage into secondary siRNAs. The silencing process is also boosted by the enzymatic activity of the RISC complex by mediating multiple turnover reactions (Hutvagner and Zamore, 2002; Tang et al., 2003). Moreover, production of the secondary siRNAs leads to the increasing activity of silencing via its spread from the first activated cell to neighboring cells, and systemically through the system (Himber et al., 2003).

The invention of RNA-binding protein (PSRP1) in the plant phloem and its capability to bind $25 \mathrm{nts}$ sRNA species add further to the argument that siRNAs (24-26 nts) are the main and unique components for systemic silencing signal (Xie and Guo, 2006). The extent of cell-to-cell movement is dependent on the levels of siRNAs produced at the site of silencing initiation, but is independent of the presence of siRNA target transcripts in either source or recipient cells (Li and Ding, 2006). 


\section{RNAi in plants}

RNA-mediated gene control technology has provided new platforms for developing environmentally friendly molecular tools for crop improvement (Umesh et al., 2012). Two main categories of small regulatory RNAs are distinguished in plants, based on their formation and function: (miRNAs) and (siRNAs). MiRNAs and siRNAs have been shown to be highly conserved, important regulators of gene expression in plants (JonesRhoades and Bartel2006; Axtell and Bowman 2008). The modes of action by which small RNAs control gene expression at the transcriptional and post-transcriptional levels are now being evolved into tools for plant molecular biology research. However, consequent work has shown that RNA silencing works on at least three different levels in plants, first is the cytoplasmic silencing by dsRNA results in cleavage of mRNA and is known as PTGS. Secondly, endogenous mRNAs are silenced by miRNAs, which negatively regulate gene expression by base pairing to specific mRNAs, resulting in either RNA cleavage or arrest of protein translation. Third, RNA silencing is associated with sequence-specific methylation of DNA and the consequent suppression of transcription (TGS) (Mansoor et al., 2006). There are evidences indicates that miRNAs are participate in biotic stress responses in plants. The first such role of miRNAs in plants was described by Jones-Rhoades and Bartel (2004). A number of miRNAs have been linked to biotic stress responses in plants, and the role of these miRNAs in plants infected by pathogenic bacteria, viruses, nematodes and fungi has been reported (Ruiz-Ferrer and Voinnet, 2009; Katiyar and Jin, 2010). Additionally, miRNAs are also important in regulating plant microbe interactions during nitrogen $(\mathrm{N})$ fixation by Rhizobium and tumour formation by Agrobacterium species (Katiyar and Jin 2010). Moreover, Mishra et al., (2009) detected a significant increase in the GC content of stress-regulated miRNA sequences, which in turn supports the view that miRNAs act as ubiquitous regulators under stress conditions. GC content may also be considered a critical parameter for predicting stress-regulated miRNAs in plants. The first plant-endogenous siRNA that was found to be involved in plant biotic stress was nat-siRNAATGB2, which regulates $\mathrm{R}$-gene mediated effector triggered immunity (Katiyar et al., 2006). A unique class of endogenous siRNA, the long siRNAs (lsiRNAs), is $30-40$ nt long and is prompted by bacterial infection or specific growth conditions, Such as cell suspension culture (Katiyar et al., 2007). However, it may be considered that generation of small RNAs is a mechanism which allows plants to modulate gene expression programmes necessary for adaptation to stressful environments. Small RNAs may facilitate the flexibility in environmental adaptation. The purpose that small RNAs have a high complexity in plants may be justified by the fact that plants growth and reproduction generally confines to many diverse and extreme habitats.

\section{Approaches to induce RNAI in plants}

A major challenge for scientists in RNAi research is to induce/suppress the specific target gene. Genes are induced by various methods. Most successful methods are virus induced gene silencing (VIGS), agroinoculation and particle bombardment. Fenselau et al., (2012) has reported VIGS as the most successful method for inducing gene activity in plants; different RNA and DNA viruses have been modified to serve as vectors for gene expression. Replication of plant viruses produces dsRNA replication intermediates very effectively and as well as efficiently because of a type of RNA silencing called VIGS (Senthilkumar et al., 2011). When viruses or transgenes are incorporated 
into plants, they trigger a post transcriptional gene silencing (PTGS) response in which dsRNA molecules, which may be generated by replicative intermediates of viral RNAs or by aberrant transgene coded RNAs (Tyagi et al., 2008). Viral RNAs not only trigger PTGS, but they also serve as targets. Cleavage of viral RNA results in reduction of virus titers in local and distant leaves and plant recovery phenotype (Godge et al., 2008).

At the same time, all RNA virus-derived expression vectors will not be useful as silencing vectors because many have potent anti-silencing proteins, which directly interfere with host silencing machinery (Diazpendon and Ding 2008). Similarly, DNA viruses have not been used extensively as expression vectors due to their size constraints for movement (Wani and Sanghera, 2010). Another one is agroinoculation, it is a powerful method to study processes connected with RNAi.

The injection of Agrobacterium carrying similar DNA constructs into the intracellular spaces of leaves for triggering RNA silencing is known as agroinoculation or agroinfiltration (Hilly and Liu, 2007). In most cases, agroinoculationis used to initiate systemic silencing or to monitor the effect of suppressor genes. In plants, cytoplasmic RNAi can be induced efficiently by agroinoculation, similar to a strategy for transient expression of $\mathrm{T}$ DNA vectors after delivery by Agrobacterium tumefaciens (Usharani et al., 2005; Karthikeyan et al., 2011). One of the important non-biologistical methods is particle bombardment. As an alternative tool, protoplast transformation was first described as a method for the production of transgenic plants in 1987 (Sanford et al., 1987). Unique advantages of this methodology are discussed in terms of the range of species and genotypes that have been engineered and with the high transformation frequencies. In plant research, the major applications of biolistics include transient gene expression studies, production of transgenic plants and inoculation of plants with viral pathogens, (Taylor and Faquet, 2002). In this method, a linear or circular template is transferred into the nucleus by micro bombardment.

Synthetic siRNAs are delivered into plants by biolistic pressure to cause silencing of green florescent protein expression. Bombarding cells with particles coated with dsRNA, siRNA or DNA that encode hairpin constructs as well as sense orantisense RNA, activate the RNAi pathway (Shabhir et al., 2010).

\section{RNA interference for engineering resistance against plant diseases}

The effects of gene silencing in plants were used in efforts to develop resistance to diseases caused by viruses, fungi and bacteria. This "pathogen-derived resistance" was achieved by transforming plants with genes, or sequences, derived from the pathogen, with the aim of blocking a specific step in the life or infection cycle of the pathogen.

\section{RNAi against plant viruses}

Plant viruses are responsible for a significant proportion of crop diseases and are very difficult to combat due to the scarcity of effective counter measures, placing them among the most important agricultural pathogens. RNAi application has resulted in successful control of many economically important viral diseases in plants,(Francisco et al., 2004; Cakir and Tor, 2010).

The effectiveness of RNAi technology for generating virus resistance in plants was first demonstrated in 1998. VIGS is one of the commonly used RNA silencing methods to control the plant viruses (Senthilkumar, et al., 2011) (Refer Table 1). 
Application of RNAi for fungal resistance development

RNA interference is a powerful and versatile genetic tool that can be applied to filamentous fungi of agricultural importance. It is shown that gene silencing plays an important role in plant defence against multicellular microbial pathogens; vascular fungi belonging to the Verticillium genus. Several components of RNA silencing pathways were tested, of which many were found to affect Verticillium defense. It is speculated that the gene silencing mechanisms affect regulation ofVerticillium specific defense responses (Ellendorff et al., 2009).

An early successful application of the RNAi system using sense and antisense RNA was reported for the pathogenic fungus Cryptococcus neoformans (Liu et al., 2002). The efficacy of RNAi was demonstrated in Magnaporthe oryzae, Venturia inaequalis, Phytophtorainfestans, Histoplasma capsulatum and Blastomyces dermatitidis by expression of GFP gene in fungus and then silencing by RNAi. Rust fungi cause devastating diseases of wheat and other cereal species globally.

Gene fragments from the rust fungus, Pucciniastriiformisf. sp. tritici or $P$. graminis f. sp. tritici, were delivered to plant cells through the Barley Stripe Mosaic Virus (BSMV) system and some reduced the expression of the corresponding genes in the rust fungus. The ability to detect suppression was associated with the expression patterns of the fungal genes because reduction was only detected in transcripts with relatively high levels of expression in fungal haustoria.

The results indicate that in planta RNAi approach can be used in functional genomics research for rust fungi and that it could potentially be used to engineer durable resistance (Yinet al., 2011). The below examples are the RNAi strategies used against different fungal species.

\section{RNA silencing-mediated resistance to plant pathogenic bacteria}

Escobar et al., (2001) for the first-time documented RNAi application for engineering re-sistance in plant against bacterial pathogen causing crown gall disease. In the particular disease, iaaM and iptoncogenes are responsible for tumourogensis (gall formation) and a pre-requisite for tumour formation. The management strategy of the disease targets these oncogenes.

With the help of RNAi technology, they showed that transgenic plants (Arabidopsis thaliana and Lycopersicon esculentum) containing modified construct of these two bacterial genes (s) showed resistance against crown gall.

The transgenic genes shut down the expression of iaaM and ipt oncogenes of the incoming bacterial pathogen, thereby disturbing the hormonal production and ultimately, tumourogenesis process after infection. Dunoyer et al., 2007 also re-ported that plants lacking the modified oncogenes were hyper-susceptible to A.tumefaciens. Another example is the RNAi-mediated enhanced resistance to Xanthomonas oryzae, the leaf blight bacterium due to successful knockdown of a rice homolog of OsSSI2 (Jiang et al., 2009). Zhai et al., 2011 and Li et al., 2012 studied the function of several miRNA families target genes of plant innate immune receptors (NBS-LRR) in Legumes and Solanaceae, respectively.

They gave a new insight into viral and bacterial infection in plants that suppresses miR482- mediated silencing of $\mathrm{R}$ genes. Considering the findings from different re- 
searchers (Zhai et al., 2011 and Li et al., 2012), a general understanding can be drawn that miRNA can either act as up-or downregulators of the bacterial invasion. The pathogen responsive miRNA effects the gene expression either by suppression of negative regulators or up regulation of the positive factors required for immune responses. Identification and characterization of pathogen responsive miRNAs that induced positive regulators of bacterial resistance, will open a flood gate to enhancement of transgenic plants that will involve the constitutive overexpression of miRNA or a miRNA.

\section{RNAi and insect pest control in agriculture}

RNAi is a powerful tool for gene function studies and control of insect pests. Several research groups have recently explored the possibility of conducting RNAi in insects through different application methods. There is a wide range of target insects from different insect orders, target genes and feeding methods, demonstrating the richness in application of dsRNA and the potentials of RNAi. Despite having been considered for many years, application of RNAi technology to give resistance to herbivorous insects has only just been realized.

The key to the success of this approach would be; (a) Insect species and its life stages (b) Type of exogenous RNA: dsRNA, siRNA, miRNA etc. (c) Dose and method of application (d) Type of target gene and its expression profile (e) Gene function and type of tissue (f) Nucleotide sequence and length of dsRNA (g) Persistence of silencing effect(h) Gut physiology.

Several crop insect pests belonging to different orders were tested for their possible control by RNAi. In these insects, RNAi knockdown has been developed for various genes encoding for developmental proteins, salivary gland proteins, proteins involved in host-insect interaction, hormone receptors and gut enzymes. Baum et al., (2007) provided evidence for the potential use of RNAi to control insects pest in crop protection and demonstrated the fact that it is possible to silence genes in insects when they consume plant material expressing hairpind RNA constructs against well-chosen target genes.

They reported the reduction of corn root damage in transgenic maize plants producing vacuolar $\mathrm{H}+\mathrm{ATPasedsRNA}$ after infestation of the plant with the western corn rootworm. In another report, the model plants Nicotiana tabacum and Arabidopsis thaliana were modified with the cytochrome P450 gene of Helicoverpa armigera.

When the cotton bollworm larvae were fed transgenic leaves, levels of cytochrome P450 mRNA were reduced and larval growth retarded (Mao et al., 2007). Bautista et al.,(2009)studied the influence of silencing the cytochrome P450 gene CYP6BG1 that is over expressed in a permethrin-resistant diamondback moth (Plutella xylostella)strain. When the gene was silenced after consumption of a droplet of dsRNA solution, the moths became significantly more sensitive to the pyrethroid insecticide. Another significant development employing RNAi is that the susceptibility of insect pests to $\mathrm{Bt}$ toxins could be enhanced by silencing of the genes involved in $\mathrm{Bt}$ resistance development.

Application of RNAi in management of biotic stress will be proved to be an incredible revolution in the field of functional genomics and a breakthrough in plant molecular genetics. If RNAi technology is developed successfully and employed for management of major diseases on commercial scale, they can prove to be an eco-friendly and biologically safe technology (Table 2). 
Table.1 Exogenous application of naked dsRNA for RNAi-mediated protection against a range of viruses/viroids on different plants

\begin{tabular}{|c|c|c|c|c|c|c|}
\hline Virus/Viroid & dsRNA target and size & $\begin{array}{c}\text { dsRNA } \\
\text { Expression } \\
\text { technique }\end{array}$ & Host & virus inoculation & Efficiency & Reference \\
\hline PMMoV & Replicase gene (977 bp) & In vitro & $\begin{array}{l}\text { N. tabacum } \\
\text { cv.Xanthi, } C \text {. } \\
\text { chinense }\end{array}$ & Co-inoculation & No lesions observed & $\begin{array}{l}\text { Tenllado and Diaz- } \\
\text { Ruiz, } 2001\end{array}$ \\
\hline PMMoV & $\begin{array}{l}\text { Replicase gene (977, } 596 \\
\text { and } 315 \mathrm{bp)}\end{array}$ & In vitro & N. benthamiana & Co-inoculation & $18 \%$ infected & $\begin{array}{l}\text { Tenllado and Diaz- } \\
\text { Ruiz, } 2001\end{array}$ \\
\hline AMV & RNA 3 (1124 bp) & In vitro & N. benthamiana & Co-inoculation & $0 \%$ infected & $\begin{array}{l}\text { Tenllado and Diaz- } \\
\text { Ruiz, } 2001\end{array}$ \\
\hline TEV & HC-Pro gene (1483 bp) & In vitro & $\begin{array}{l}\text { N. tabacum } \\
\text { cv.Xanthi }\end{array}$ & Co-inoculation & $0 \%$ infected & $\begin{array}{l}\text { Tenllado and Diaz- } \\
\text { Ruiz, } 2001\end{array}$ \\
\hline PMMoV & Replicase gene (977 bp) & $\begin{array}{l}\text { Bacterial HT115 } \\
\text { expression }\end{array}$ & N. benthamiana & $\begin{array}{l}\text { Co-inoculation; Sprayed } \\
\text { dsRNA and challenged, } 3 \text {, } \\
\text { 5, } 7 \text { days post-spray }\end{array}$ & $\begin{array}{l}\text { Days 1-5: } 0 \% \text { infected } \\
\text { Day 7: } 80 \% \text { infected }\end{array}$ & Tenllado et al., 2003a \\
\hline PMMoV & $\begin{array}{l}\text { CP gene }(1081 \mathrm{bp}) \mathrm{HC}- \\
\quad \text { Pro gene }(1492 \mathrm{bp})\end{array}$ & $\begin{array}{l}\text { Bacterial HT115 } \\
\text { expression }\end{array}$ & N. benthamiana & $\begin{array}{l}\text { Co-inoculation; Sprayed } \\
\text { dsRNA and challenged } 5 \\
\text { days post-spray }\end{array}$ & $\begin{array}{c}\text { CP: } 27 \% \text { infected } \\
\text { HC-Pro: } 17.6 \% \text { infected }\end{array}$ & Tenllado et al., $2003 \mathrm{~b}$ \\
\hline CEVd & $\begin{array}{l}\text { Less than full-length } \\
\text { dsRNA }\end{array}$ & In vitro & $\begin{array}{l}\text { Gynuraaurantia } \\
\text { ca, Tomato }\end{array}$ & Co-inoculation & $50 \%$ infected & Carbonell et al., 2008 \\
\hline PSTVd & $\begin{array}{l}180 \text { bp (nucleotide } \\
\text { Position 1-179) }\end{array}$ & In vitro & Tomato & Co-inoculation & $\begin{array}{l}100 \% \text { infected, some } \\
\text { plants showed delay in } \\
\text { symptoms }\end{array}$ & Carbonell et al., 2008 \\
\hline CChMVd & $\begin{array}{l}\text { Less than full-length } \\
\text { dsRNA }\end{array}$ & In vitro & Chrysanthemum & Co-inoculation & $50 \%$ infected & Carbonell et al., 2008 \\
\hline TMV & CP gene (480 bp) & $\begin{array}{c}\text { Bacterial M-JM109 } \\
\text { lacY expression }\end{array}$ & Tobacco & Co-inoculation & $50 \%$ infected & Yin et al., 2009 \\
\hline SCMV & $\begin{array}{c}\text { CP gene (CP1: } 147 \mathrm{bp}, \\
\text { CP2:140 bp) }\end{array}$ & $\begin{array}{c}\text { Bacterial HT115 } \\
\text { expression }\end{array}$ & Maize & $\begin{array}{l}\text { Co-inoculation. Sprayed } \\
\text { dsRNA and challenged } 1,3 \text {, } \\
5,7 \text { and } 9 \text { days post-spray }\end{array}$ & $\begin{array}{c}\text { Co-inoculation } \\
\text { CP-1: } 20 \% \text { infected } \\
\text { CP-2: } 30 \% \text { infected } \\
\text { Day 1: } 0 \% \text { infected } \\
\text { Day 3: } 4 \% \text { infected } \\
\text { Day 5: } 12 \% \text { infected }\end{array}$ & Gan et al., 2010 \\
\hline
\end{tabular}


Int.J.Curr.Microbiol.App.Sci (2019) 8(11): 1100-1111

\begin{tabular}{|c|c|c|c|c|c|c|}
\hline & & & & & $\begin{array}{c}\text { Day 7: } 43.3 \% \text { infected } \\
\text { Day 9: } 72 \% \text { infected }\end{array}$ & \\
\hline PVY & $\begin{array}{l}\text { NIb gene (3 different } \\
\text { dsRNAs, all } 500 \mathrm{bp} \text { ) }\end{array}$ & $\begin{array}{c}\text { Bacterial M-JM109 } \\
\text { lacY expression }\end{array}$ & Tobacco & Co-inoculation & $\begin{array}{l}\text { NIb-1: } 34 \% \text { infected } \\
\text { NIb-2: } 66 \% \text { infected } \\
\text { NIb-3: } 52 \% \text { infected }\end{array}$ & Sun et al., 2010a \\
\hline PVY & $\begin{array}{l}\text { HC-Pro gene, Nibgene CP } \\
\text { gene (all } 600 \text { bp each) }\end{array}$ & $\begin{array}{l}\text { Bacterial HT115 } \\
\text { expression }\end{array}$ & Tobacco & Co-inoculation & $\begin{array}{l}\text { NIb: } 28 \% \text { infected } \\
\text { HC-Pro: } 54 \% \text { infected } \\
\text { CP: } 44 \% \text { infected }\end{array}$ & Sun et al., 2010 b \\
\hline TMV & $\begin{array}{l}\text { MP gene, CP gene, RP } \\
\text { gene (all } 480 \text { bp each) }\end{array}$ & $\begin{array}{l}\text { Bacterial HT115 } \\
\text { expression }\end{array}$ & Tobacco & Co-inoculation & $\begin{array}{l}\text { MP: } 34 \% \text { infected } \\
\text { CP: } 52 \% \text { infected } \\
\text { RP: } 66 \% \text { infected } \\
\text { RNA: } 60 \% \text { infected }\end{array}$ & Sun et al., $2010 \mathrm{~b}$ \\
\hline PRSV & CP gene (279 bp) & $\begin{array}{c}\text { Bacterial M-JM109 } \\
\text { lacY expression }\end{array}$ & Papaya & $\begin{array}{l}\text { Co-inoculation. Sprayed } \\
\text { dsRNA and challenged } 1,2 \text {, } \\
3 \text { and } 5 \text { days post-spray }\end{array}$ & $\begin{array}{c}\text { Co-inoculation } 35 \% \\
\text { infected. } \\
\text { All others: } 100 \% \text { infected }\end{array}$ & Shen et al., 2014 \\
\hline PSbMV & CP gene $(500 \mathrm{bp})$ & In vitro & Pea cv. Raman & $\begin{array}{l}\text { dsRNA sprayed and Co- } \\
\text { inoculated with virus. } \\
\text { dsRNA was sprayed after } \\
1,2 \text { and } 21 \text { days post- } \\
\text { inoculation. }\end{array}$ & $\begin{array}{l}\text { All } 100 \% \text { infected, } \\
\text { reduced viral titre }\end{array}$ & Safarova et al., 2014 \\
\hline CymMV & CP gene (237 bp) & $\begin{array}{l}\text { Bacterial HT115 } \\
\text { expressions }\end{array}$ & Orchid & Co-inoculation & $20 \%$ infected & Lau et al., 2014 \\
\hline TMV & $\begin{array}{c}\text { p126 (666 bp), CP gene } \\
\text { (480 bp) }\end{array}$ & In vitro & $\begin{array}{l}\text { N. tabacum } \\
\text { cv.Xanthi }\end{array}$ & Co-inoculation & $\begin{array}{l}\text { p126: } 35 \% \text { infected } \\
\text { CP: } 50 \% \text { infected }\end{array}$ & Konakalla et al., 2016 \\
\hline ZYMV & HC-Pro, CP gene & In vitro & $\begin{array}{l}\text { Cucumber, } \\
\text { Watermelon and } \\
\text { Squash plants }\end{array}$ & Co-inoculation & $\begin{array}{c}\text { HC-Pro (Cucumber)- 82\% } \\
\text { HC-Pro (Watermelon)- } \\
50 \% \\
\text { HC-Pro (Squash)- } 18 \% \\
\text { CP (Cucumber)- 70\% } \\
\text { CP (Watermelon)- 43\% } \\
\text { CP (Squash)- 16\% }\end{array}$ & Kaldis et al., 2018 \\
\hline
\end{tabular}

AMV, Alfalfa mosaic virus; CChMVd, Chryanthemum chlorotic mottle viroid; CEVd, Citrus exocortis viroid; CP, coat protein; RP, Replicase protein; CymMV, Cymbidium mosaic virus; HC-Pro, Helper Component Protein; NIb, Nuclear Inclusion b; MP, Movement Protein; PMMoV, Pepper mild mottle virus; PPV, Plum pox virus; PRSV, Papaya ringspot virus; PSbMV, Pea seed borne mosaic virus; PSTVd, Potato spindle tuber viroid; PVY, Potato virus Y; p126, Protein 126,

RP, Replicase Protein; SCMV, Sugarcane mosaic virus; TEV, Tobacco etch virus; TMV, Tobacco mosaic virus; ZYMV, Zucchini yellow mosaic virus 
Table.2 RNAi against fungal pathogens

\begin{tabular}{|c|c|c|}
\hline Pathogen & Targeted Region & Reference \\
\hline Magnaporthe oryzae & $e G F P$ & Kadotaniet al.(2003) \\
\hline $\begin{array}{c}\text { Cladosporium falvum } \\
\text { F. oxysporum } \text { f. sp. } \\
\text { conglutinans }\end{array}$ & $\begin{array}{c}\text { cgll and cgl2 } \\
\begin{array}{c}\text { Blumeria graminis } \\
\text { f.sp. tritici }\end{array}\end{array}$ & Segerset al.(1999) \\
\hline $\begin{array}{c}\text { Blumeria graminis } \\
\text { Venturia inaequalis }\end{array}$ & $\begin{array}{c}\text { Multiple inverted } \\
\text { repeats }\end{array}$ & Zongliet al. (2015) \\
\hline
\end{tabular}

Moreover, this technique eliminates the risk associated with development of transgenics and it will also gener-ate enormous potential for engineering control of gene expression. An agronomically superior cultivar can be engineered for additional plant fitness by using RNAi technology. However, selection of targeting sequence and deliver of siRNA is a major challenge for plant molecular biologists. More understanding and exploration in the field of RNAi promoting resistance is need-ed. Therefore, further molecular research is needed to unfurl the factors affecting RNAi-mediated resistance and solved all the challenges in delivering the siRNA to the host system and identifying the targeted region to effectively overcome the pathogen and promote crop improvement

\section{References}

Axtell MJ, Bowman JL. 2008. Evolution of plant microRNAs and their targets. Trends Plant Sci.13:343-349.

Baum JA, Bogaert T, Clinton W, Heck GR, Feldmann $\mathrm{P}$, Ilagan $\mathrm{O}$, Johnson $\mathrm{S}$, Plaetinck G,

Bautista MA, Miyata T, Miura K, Tanaka T (2009) RNA interference-mediated knockdown of acytochrome P450, CYP6BG1, from the diamondback moth, Plutella xylostella, reduces larval resistance to permethrin. Insect Biochem Mol Biol 39:38-46

Cakir C, Tor M. 2010. Factors influencing barley stripe mosaic virus-Mediated gene silencing in wheat. PhysiolMol Plant Pathol. 74:246-253.

Diaz-Pendon JA, Ding SW. 2008. Direct and indirect roles of viral suppressors of RNA silencing in pathogenesis. Annu Rev Phytopathol. 46:303-326.

Dimitar, D., Stefanie, L., Annika, J., Daniela, Axel, H., Jeya-raman, R., Nils, S., Rajiv, S., Benjamin, K. and Patrick, S. (2014). Discovery of genes affecting resistance of barley to adapted and non-adapted powdery mildew fungi. Genome boil., 15:518.

Dunoyer, P., Himber, C., Ruiz-Ferrer, V., Alioua, A. and Voinnet, O. (2007). Intra- and Intercellular RNA Interference in Arabidopsis thaliana Requires Components of the MicroRNA and Heterochromatic Silencing Path-ways. Nat.Genet., 39:848-856.

E. Bernstein, A. A. Caudy, S. M. Hammond and G. J.Hannon, "Role for a Bidentate Ribonuclease in the Initiation Step of RNA Interference," Nature, Vol. 409, 2001, pp. 363-366.

Ellendorff U, Fradin EF, de Jonge R, Thomma BPHJ (2009) RNA silencing is 
required for Arabidopsis defense against Verticillium wilt disease. J Exp Bot 60: 591-602

Escobar, M.A., Civerolo, E.L., Summerfelt, K.R. and Dan-dekar, A.M. (2001). RNA imediated oncogene silencing confers resistance to crown gall tumorigenesis. PNAS, 98:1343713442.

Fenselau F, Jiawei W, Detlef W. 2012. MIGS: miRNA-induced gene silencing. Plant J. 70:541-547.

Fire, A., S. Xu, M. K. Montgomery, S. A. Kostas, S.E Driver and C. C. Mello, "Potent and Specific Genetic Interference by Double-Stranded RNA in Caenorhabditis elegans," Nature, Vol. 391, 1998, pp. 806-811.

Fitzgerald, A., Van, Kha, J.A. and Plummer, K.M. (2004). Simultaneous Silencing of Multiple Genes in the Apple Scab Fungus Venturia inaequalis, by Expression of RNA with Chimeric Inverted Repeats. Fungal Genet. Biol., 41: 963-971.

Francisco T, Cesar L, Ramon L, Diaz-Ruiz. 2004. RNA interference as a new biotechnological tool for the control of virus diseases in plants. Virus Res. 102(1): 85-96.

Godge MR, Purkayastha A, Dasgupta I, Kumar PP. 2008. Virus-induced gene silencing for functional analysis of selected genes. Plant Cell Rep. 27: 209-219.

Hammond, S. M., E. Bernstein, D. Beach and G. J. Hannon, "An RNA-Directed Nuclease Mediates PostTranscriptional Gene Silencing in Drosophila Cells," Nature, Vol. 404, 2000, pp. 293-296.

Hannon GJ, "RNA Interference," Nature, Vol. 418, 2002, pp. 244-251.

Himber, C., P. Dunoyer, G. Moissiard, C. Ritzenthaler andO. Voinnet, "Transitivity Dependent and
Independent Cell-to-Cell Movement of RNA Silencing," The EMBO Journal, Vol. 22, 2003, pp. 4523-4533

Hutvagner, G. and P. D. Zamore, "A microRNA in a Multiple-Turnover RNAi Enzyme Complex," Science, Vol. 297, 2002, pp. 2056-2060.

Jiang, C.J., Shimono, M., Maeda, S., Inoue, H., Mori, M., Hasegawa, M., Sugano, S. and Takatsuji, H. (2009). Suppression of the rice fatty-acid desaturase gene Os-SSI2 enhances resistance to blast and leaf blight diseases in rice. Mol. Plant-Microbe Interact., 22: 820-829.

Jones-Rhoades MW, Bartel DP. 2006. MicroRNAs and their regulatory roles in plants. Annu Rev Plant Biol. 57:1953.

Kadotani N, Nakayashiki H, Tosa Y, Mayama $S$ (2003) RNA silencing in the pathogenic fungus Magnaporthe oryzae. Molecular Plant-Microbe Interaction 16, 769-776

Kumar S (2013). Plant disease management under changing climatic scenario. J. Mycol Plant Pathol. 42(2):149-154.

Li F, Ding SW (2006) Virus counter defense: diverse strategies for evading the RNA silencing immunity. Annual Review of Microbiology 60, 503-531

Li, X., Wang, X., Zhang, S., Liu, D., Duan, Y. and Dong, W. (2012). Identification of soybean microRNAs involved in soybean cyst nematode infection by deep sequencing. PLoS ONE doi:10.1371/journal.pone. 0039650.

Liu H, Cottrell TR, Pierini LM, Goldman WE, Doering TL (2002) RNA interference in the pathogenic fungus Cryptococcus neoformans. Genetics 160:463-470.

Mansoor, M, Imran, A, Mazhar, H, Yusuf, Z, Rob W. Briddon. 2006. Engineering novel traits in plants through RNA interference. Trends Plant Sci. 11(11): 559-565. 
Mao YB, Cai WJ, Wang JW, Hong GJ, Tao XY, Wang LJ, Huang YP, Chen XY (2007) Silencing a cotton bollworm P450 monooxygenase gene by plantmediated RNAi impairs larval tolerance of gossypol. Nat Biotechnol 25:1307-1313.

Mishra AK, Agarwal S, Jain CK, Rani V. 2009. High GC content: critical parameter for predicting stress regulated miRNAs in Arabidopsis thaliana. Bioinformation. 4:151-154.

Munyikwa T, Pleau M, Vaughn T, Roberts J (2007) Control of coleopteran insect pests through RNA interference. Nat Biotechnol 25:1322-1326

P. Dunoyer, C. Himber, V. Ruiz-Ferrer, A. Alioua and O. Voinnet, "Intra- and Intercellular RNA Interference in Arabidopsis thaliana Requires Components of the MicroRNA and Heterochromatic Silencing Pathways," Nature Genetics, Vol. 39, 2007, pp. 848-856.

Pickford AS and Cogoni C (2003) "RNAMediated Gene Silencing," Cellular and Molecular Life Science, Vol. 60, 2003, pp. 871-882.

Ruiz-Ferrer V, Voinnet O. 2009. Roles of plant small RNAs in biotic stress responses. Annu RevPlant Biol. 60:485-510.

Sanford JC, Klein TM, Wolf ED, Allen N. 1987. Delivery of substances into cells and tissues using a particle bombardment process. J Par Sci Technol. 5:27-37.

Schweizer, P., Pokorny, P., Schulze-Lefert, P. and Dud-ler, R.(2000). Double Stranded RNA Interference with Gene Functions at the Single Cell in Cereals. Plant J., 24: 895-903.

Segers GC, Hamada W, Oliver RP, Spanu PD (1999) Isolation and characteristaion of five different hydrophobin-encoding cDNA from the fungal tomato pathogen Cladosporium fulvum. Molecular and General Genetics 261,644-652

Senthilkumar M, Mysore KS. 2011. Virusinduced gene silencing can persist for more than two years and also be transmitted to progeny seedlings in Nicotiana benthamiana and tomato. Plant Biotechnol J. 9:797-806.

Shabhir HW, Gulzar SS, Singh NB. 2010. Biotechnology and plant disease control-role of RNA interference. Am J Plant Sci. 1: 55-68.

Shabhir HW, Gulzar SS, Singh NB. 2010. Biotechnology and plant disease control-role of RNA interference. Am J Plant Sci. 1: 55-68.

Tang, G., B. J. Reinhart, D. Bartel and P. D. Zamore, "A Biochemical Framework for RNA Silencing in Plants," Genes and Development, Vol.17, 2003, pp. 49-63.

Taylor NJ, Fauquet CM. 2002. Microparticle bombardment as a tool in plant science and agricultural biotechnology. DNA Cell Biol. 21: 963-977.

Tyagi H, Rajasubramaniam S, Rajam MV, Dasgupta I. 2008. RNA interference in rice against ice Tungro Bacilliform virus results in its decreased accumulation in inoculated rice plants. Transgenic Res. 17: 897-904.

Umesh BJ, Ranjit GG, Vishwas AB. 2012. Role of RNA interference in plant improvement. Naturwissenschaften. 1:1913-1919.

Usharani KS, Surendranath B, Haq QMR, Malathi VG. 2005. Infectivity analysis of a soybean isolate of Mungbean yellow mosaic India virus by agroinoculation. J Gen Plant Pathol.71:230-237.

Voinnet, O, "Non-Cell Autonomous RNA Silencing," Federation of European Biochemical Societies Letters, Vol. 579, 2005, pp. 5858-5871. 
Wani SH, Sanghera GS. 2010. Genetic engineering for viral disease management in plants. Notulae Scientia Biologicae. 2:20-28.

Waterhouse PM, Wang MB, Lough T (2001) Gene silencing as an adaptive defense against viruses. Nature 411, 834-842

Xi Q, Guo H (2006) Systemic antiviral silencing in plants. Virus Research $118,1-6$.

Yin C, Jurgenson JE, Hulbert SH (2011) Development of a Host-Induced RNAi System in the Wheat Stripe Rust Fungus Puccinia striiformis f. sp.
Tritici. MPMI 24:554-561

Zhai, J., Jeong, D.H., DePaoli, E., Park, S., Rosen, B.D. and Li, Y. (2011). Micro RNAs as master regulators of the plant NB-LRR defense gene family via the production of phased, trans- acting siRNAs. Genes Dev. 25:2540-2553. doi: 10.1101/gad.177527.111

Zongli, H., Urvi, P., Natsumi, M., Yuri, T. and Jose, R.B. (2015) Down regulation of Fusarium oxysporum endogenous genes by Host-Delivered RNA interference enhances disease resistance. Frontiers in chem.3: 1-10.

\section{How to cite this article:}

Munmi Borah and Naga Charan Konakalla. 2019. RNA Interference and its Application in Crop Protection. Int.J.Curr.Microbiol.App.Sci. 8(11): 1100-1111. doi: https://doi.org/10.20546/ijcmas.2019.811.130 